\title{
KARAKTERISTIK PEMIKIRAN USUL AL-FIQH IMAM AL-GHAZALI \\ DALAM KITAB AL-MUSTASFA MIN'ILM AL-USUL
}

\author{
Oleh: Ihasan \\ (ihasan@yahoo.com) \\ STAIS Bangkalan
}

\begin{abstract}
Imam al-Ghazali is a writer and thinker encyclopedic. The work of alGhazali covers a wide range of scientific branches of Islam. Theology, philosophy, tasawwuf and jurisprudence (fiqh). Al-Ghazali describes the scientific conception of usulal-fiqh, including definition of usul al-fiqh. Its position in the structure and scope os Islamic scholarship. Al-Ghazali defines the usul al-fiqh as a science that examines the sources (orgins) law, the terms of validity and model, structure and method of oppointment to the law. Usul al-fiqh as defined is a noble thought is a science because it has the potential of combining reason and revelation. Discipline is explicitly different from the science of kalam (theology) which is "kulli" an Islamic science that is particular, because it is concerted is a discussion on the legal arguments of personality. It's as tafsir, hadith, and tasawwuf. In hierarchic usulalfiqh under the umbrella of theology.
\end{abstract}

Keyword: science, suggestion, al-fiqh.

\section{A. PENGANTAR}

Imam al-Ghazali adalah penulis dan pemikir ensiklopedis. Nicholson pernah berandai-andai bahwa seandanya masih ada Nabi setelah Muhammad, tentu alGhazali-lah orangnya. Itu tidak terlepas dari curiosity al-Ghazali terhadap ilmu pengetahuan dan kebenaran. Karya-karya al-Ghazali mencakup berbagai cabang keilmuan Islam; teologi, filsafat, tasawwuf dan yurisprudensi (fiqh). Akan tetapi pemikirannya dalam bidang yurisprudensi tidak sepopuler pemikirannya dalam bidang keilmuan yang lain, sebagaimana ia lebih dikenal sebagai ahli tasawwuf, filsafat dan teologi. ${ }^{1}$ Karena itu mengangkat pemikiran al-Ghazali dalam bidang fiqh cukup signifikan, selain untuk memberikan apresiasi yang berimbang terhadap pemikiran al-Ghazali, juga untuk melihat interkoneksi pemikiran usul-nya dengan disiplin lain yang dikuasainya. Asumsinya adalah bahwa pemikiran fiqh yang

\footnotetext{
1 Syamsul Arifin dalam disertasinya menampilkan beberapa penilaian terhadap al-Ghazali sebagaimana dilontarkan Margareth Smith, Hasan Ibrahim Hasan dan Goldziher yang lebih menampilkan Imam al-Ghazali sebagai pemikir dalam bidang teologi, filsafat dan tasawwuf daripada fiqh. Kemudian Arifin mengidentifikasi argumentasi-argumentasi yang menguatkan bahwa nuansa pemikiran fiqhiyyah dalam diri al-Ghazali cukup dominan. Lihat Syamsul Anwar, Epistemologi Hukum Islam dalam al-Mustasfa min 'Ilm al-Usul Karya Imam al-Ghazali (450 - 505 H/1058 1111 M) (Yogyakarta: IAIN Sunan Kalijaga, 2000), 52.
} 
mengambil jarak dengan keilmuan Islam yang lain cenderung bersifat legal-formal daripada subtansial.

Selain itu, pemikiran tokoh tidak terlepas dari setting sosial budaya yang mengitarinya. Sebutan al-Ghazali sebagai Hujjah al-Islam tidak terlepas dari peran yang dimainkan dalam memproteksi Islam dan melawan trend pemikiran waktu itu. Ibn Khaldun, Bapak Sosiologi Islam, menegaskan bahwa al-rajul ibn bi'atih (seseorang adalah anak zaman dan lingkungannya). Itu artinya persepsi kultural, posisi sosial dan tendensi personal seseorang bagaimanapun sulit untuk dihilangkan sama sekali. Karena itu tulisan ini akan diawali dengan penelusuran terhadap biografi al-Ghazali.

Studi pemikiran usulal-fiqh al-Ghazali ini akan difokuskan pada karya masterpiece-nya, al-Mustasfa min 'Ilm al-Usul. Pemikirannya, khusunya dalam bidang $u s u l$, yang terkodifikasikan dalam kitab ini dianggap sebagai pemikiran matang dan final al-Ghazali. Karena itu menarik untuk mencoba menela`ah kitab ini dalam rangka melihat kerangka keilmuan usulal-fiqh sebagaimana telah ditawarkan al-Ghazali. Selain itu, tulisan ini juga akan mencoba mengangkat persoalan logic dan qiyas usul al-fiqh menurut al-Ghazali, mengingat bahasan ini penulis anggap menjadi diskursus yang khas dari Kitab al-Ghazali.

\section{B. BIOGRAFI IMAM AL-GHAZALI}

\section{1) Al-Ghazali dan Lingkungan Keluarga}

Nama lengkapnya adalah al-Shaykh al-Imam al-Bahr Muhammad b. Muhammad b. Muhammad b. Ahmad al-Tusi al-Imam al-Jalil Abu Hamid alGhazali ${ }^{2}$ al-Shafi'i. Gelar al-Shafi'I karena al-Ghazali bermadzab Shafi'iyyah, Abu Hamid karena salah satu anaknya bernama Hamid dan al-Ghazali al-Tusi karena profesi ayahnya sebagai pemintal bulu kambing dan ia dilahirkan di Ghazalah, Bandar Thus, Khurasan pada tahun 450 H/1058 M. ${ }^{3}$ Tidak banyak yang bisa diungkap tentang lingkungan keluarganya, kecuali secara global saja. Ia lahir dari

\footnotetext{
2 Abu Hamid Muhammad b. Muhammad b. Muhammad al-Ghaza>li, Al-Mustasfa min 'Ilm al-Usul (Beirut: Dar Ihya`al-Turath al-'Arabi, 1997), 9.

${ }^{3}$ http://id.wikipedia.org/wiki/Al-Ghaza> li\#Catatan, Akses Maret 2018. 
keluarga miskin tapi mempunyai tingkat religiusitas yang tinggi. Ayahnya, Muhammad, di sela-sela kesibukannya mencari nafkah secara rutin menghadiri majlis-majlis pengajian ulama`. Karenanya, Muhammad bercita-cita anak-anaknya menjadi sosok-sosok yang 'alim dan shalih. Akan tetapi, Muhammad meninggal sebelum melihat mereka berproses menjadi apa yang ia inginkan. Muhammad meninggal sebelum anaknya, al-Ghazali, berusia enam tahun. Walau begitu, do'a sang ayah terkabulkan, kedua anaknya menjadi ulama besar, al-Ghazali menjadi penulis dan pemikir sementara saudara laki-lakinya, Majduddin (w. $520 \mathrm{H}$ ), menjadi da'i.

Sejak kecil al-Ghazali dididik dengan akhlak yang mulia. Karenanya ia sangat membenci kesombongan, ketamakan, kedengkian, kemewahan dan akhlak-akhlak tercela lainnya. Sebaliknya ia sangat menyukai peribadatan, wara' dan sikap zuhud. Al-Ghazali menikah sebelum usia 20 tahun. Pendapat lain mengatakan bahwa alGhazali menikah saat usia 34 tahun. Pendapat yang terakhir ini kelihatanya lebih kuat bila dilihat dari karakter al-Ghazali dan kesibukannya dalam studi. Informasi tentang istrinya tidak banyak yang bisa mengungkap. Al-Ghazali mempunyai 3 anak perempuan.

\section{2) Pendidikan dan Karir Al-Ghazali}

Berdasarkan wasiat ayahnya, pendidikan dan pengasuhan al-Ghazali selanjutnya diserahkan pada Ah \}mad b. Muh \}ammad al-Razikani. Ia adalah teman ayahnya dari Tus yang ahli tasawwuf dan fiqh. Setelah harta wasiat ayahnya habis, al-Ghazali disarankan al-Razikani untuk masuk madrasah yang memberikan beasiswa penuh. Di kampung halamannya ini al-Ghazali mempelajari dasar-dasar fiqh.

Setelah itu ia merantau ke Jurja>n, sebuah kota di Persia yang terletak antara Tabristan dan nisabur, untuk belajar pada Abu Nasr al-Isma'ili. Dari Abu Nasr ini al-Ghazali banyak membuat catatan-catan fiqh yang sering kali disebut dengan alta'liqah. Setelah itu ia kembali ke Tus, kampung halamannya. Di Tus al-Ghazali banyak menelaah al-ta'liqah-nya yang diperoleh dari Jurjan sebelum ia berangkat lagi ke Nisabur. Di Nisabur, ia masuk lembaga pendidikan Nizamiyyah di bawah 
ampuan Imam Abu al-Ma'ali al-Juwayni, seorang teolog Ash'ariyyah yang terkenal. ${ }^{4}$ Dari al-Juwayni, al-Ghazali tidak saja belajar disiplin teologi, akan tetapi juga fiqh, logika, dan filsafat. Al-Ghazali menghabiskan masa studi di perguruan Nizamiyyah selama 8 tahun hingga gurunya, al-Juwayni meninggal (478 H/1085 M). Sebelum gurunya meninggal, al-Ghazali sempat membukukan catatan-catatan kuliah fiqhnya dari sang guru. Bukunya tersebut ia beri judul al-Mankhul min Ta'liqat al-Usul. Tidak berlebihan bila kemudian, al-Juwayni melihat al-Ghazali sebagai sosok mahasiwa yang berprestasi dan menjadikannya sebagai asisten.

Setelah selama 8 tahun bersama al-Juwayni, tepatnya usia 28 tahun, alGhazali pergi ke Mu'askar berdekatan dengan pusat pemerintahan Nizam al-Mulk. Di tempat ini al-Ghazali tetap setia melaksanakan kegiatan-kegiatan akademis dengan melibatkan orang-orang ternama kala itu. Profesionalitas al-Ghazali mendapatkan simpati menteri Nizam al-Mulk, sehingga pada usia ke-34 tahun, alGhazali diangkat sebagai guru besar lembaga pendidikan di Baghdad yang didirikan menteri tersebut. Ia menekuni profesi tersebut selama 4 tahun.

Keterlibatannya secara intens dalam dunia karir dan akademis pada akhirnya menimbulkan kepenatan dan problem epistemologis dalam diri al-Ghazali. Ia menyangsikan track menggapai kebenaran yang selama ini ia tempuh. Hal ini mendorong al-Ghazali menarik diri dari karir publik di Baghdad (488 H/1095 M) bertepatan dengan usianya yang ke-38 dan memutuskan untuk melakukan safari spiritual-intelektual (tujuan: Syam, Mekkah dan Damaskus), meditasi dan refleksi untuk menemukan hakikat jalan kebenaran. Setelah mempertimbangkan jalan kebenaran kaum teolog, ${ }^{5}$ filosof ${ }^{6}$ dan batini, ${ }^{7}$ al-Ghazali akhirnya menjatuhkan

\footnotetext{
4 Eva Y.N. at. al. (pent.), "al-Ghazali, Abu Hamid”, Ensiklopedi Oxford (Jakarta: Mizan, 2002), 111.

${ }^{5}$ Kaum teolog menurut al-Ghazali terlalu mempersoalkan hal-hal sepele yang tidak bersentuhan dengan kehidupan konkrit. Karenanya tidak berkontribusi terhadap penyelesaian problem sosial kala itu. Ibid.

6 Al-Ghazali sebenarnya tidak menkritik wacana filsafat secara keseluruhan. Tetapi kritiknya terutama diarahkan pada diskursus metafisika yang menurutnya ibarat memintal jaring laba-laba metafisis yang tidak subtansial arahan tradisi filsafat Yunani. Ibid.

7 Kaum esoteris Batini menurutnya tidak PD dengan kemampuan sendiri dan menggantungkan bahwa pengetahuan hanya bisa didapat dari Imam yang sempurna. Lihat, Ibid.
} 
pilihan pada jalan sufi. ${ }^{8}$ Jalan sufi menurutnya telah mensintesakan aspek teoritis dan keimanan dengan aspek pengalaman dan praktek, dan inilah yang dikehendaki oleh Islam. ${ }^{9}$ Kritik al-Ghazali pada dasarnya tidak ditujukan pada disiplin keilmuannya, akan tetapi pendekatan dan persepsi para ahlinya yang tidak tepat. Menurutnya disiplin keislaman harus dikonstruksikan pada spiritualisasi pemikiran dan praktek keagamaan; bentuk harus diberi ruh dan hukum serta ritual harus diberi visi etis. Dalam bidang hukum misalnya, kasuistri - penilaian benar atau salah dengan merujuk pada teori hukum dan konvensi sosial misalnya - adalah hal yang tercela karena telah mengorbankan ruh atau tujuan hukum (maqasid al-shari'ah).

Setelah sebelas tahun melakoni jalan sufi, al-Ghazali merasa terpanggil kembali untuk menekuni profesinya, mengajar. Profesi ini menurutnya cukup signifikan untuk merespon perkembangan sosial budaya dan keagamaan waktu itu yang memprihatinkan, yakni; semakin berkembangnya sekularisasi filsafat, sempalisasi tasawwuf, perkembangan ajaran batiniah dan para pemuka agama yang cenderung korup. Keterlibatannya kembali pada dunia akademis membuatnya dipanggil kembali untuk menjadi guru besar di PT Nizamiyyah, Nisabur. Berangkatlah al-Ghazali untuk memenuhi panggilan ini pada tahun 499 H/1106 M. Ia mengajar di Nizamiyyah ini selama 3 tahun dan pada masa ini, atas permintaan mahasiswanya, ia menulis al-Mustasfa min Usulal-fiqh untuk kepentingan kuliah hukum.

Di akhir hayatnya, al-Ghazali kembali ke Tus, kampung halamannya, untuk mengisi masa pensiun dengan mendirikan lembaga pendidikan dan monasteri, tempat untuk kontemplasi para sufi. Akhirnya, al-Ghazali meninggal pada di Tus pada $505 \mathrm{H} / 1111 \mathrm{M}$.

\footnotetext{
8 Selain itu ada beberapa alasan yang dilontarkan al-Ghazali terkait dengan keterlibatannya dengan tasawwuf dan kepergiannya meninggalkan Baghdad; melakukan penyelidikan kebenaran ajaran sufi, situasi politik dan kebobrokan moral saat itu dan keinginannya untuk menimba ilmu tasawwuf dari Abu al-Fath Nasir b. Ibrahim al-Maqdisi al-Nabulusi. Lihat Syamsul Anwar, Epistemologi, 80.

9 Sebagai misal, para sufi menurutnya telah mengalami realitas-realitas yang hanya diwacanakan oleh para teolog.
} 


\section{3) Karya-Karya al-Ghazali}

Karya-karya al-Ghazali mencapai 200-an judul. Obyektivitas dan ketulusannya mempengaruhi banyak khalayak pada eranya. Bahkan sampai era komtemporer ini tulisannya tidak lekang oleh waktu. Karya-karyanya banyak mendapatkan apresiasi, tidak saja oleh sarjana Muslim akan tetapi juga sarjana Barat dalam bentuk penterjemahan, kritik atau dukungan. Semua apresiasi tersebut pada esensi adalah upaya menafsir dan menkontekstualisasikan pemikiran alGhazali. ${ }^{10}$

Hal tersebut di atas dikarenakan karya-karyanya, baik dalam subtansi atau metode, mempunyai ciri "modern". Karya-karyanya secara umum bermuatan kritik atas taqlid, pencarian prinsip-prinsip dasar keilmuan Islam, keberpihakannya pada moralitas yang semuanya dilakukan dalam bingkai obyektivitas pendekatan. ${ }^{11}$ Akan tetapi, afiliasinya pada sistem teologi Ash'ariyyah yang bersifat diametral dengan konsepsi teologi Mu'tazilah, karya magnum opus filsafatnya Tahafut al-Falasifah, dan karya Ihya-nya yang bernuansa 'irfani dijadikan argumentasi oleh sebagian sarjana untuk menuduh al-Ghazali sebagai biang degradasi intelektual Islam. ${ }^{12}$ Padahal kemunduran intelektual Islam mungkin lebih disebabkan karena khalayak terlalu fanatik terhadap al-Ghazali, sehingga yang diwarisi bukan bangunan epistemologinya dan curiosity-nya terhadap kebenaran hakiki, akan tetapi produk pemikirannya yang berkarakter historis.

Apa yang dilakukan al-Ghazali pada dasarnya adalah sebentuk usaha integralisasi dan penyatuan keilmuan Islam. Ketekunan dan karya-karyanya dalam berbagai keilmuan Islam (teologi, tasawwuf, fiqh) serta konsentrasinya pada filsafat dan logika adalah untuk memahami Islam secara kaffah. Akan tetapi usahanya tersebut dianggap telah menodai agama atau rasionalisme itu sendiri. Bagi yang berpandangan demikian menganggap agama dan filsafat adalah entitas yang bersifat

\footnotetext{
${ }^{10}$ Eva Y.N. at. al. (pent.), "al-Ghazali, Abu Hamid”, 113.

11 Ibid

12 http://www.goodreads.com/story/show/12243.EPISTEMOLOGI_FILSAFAT_AL_GHOZALI, Akses Maret 2008.
} 
terpisah (separate entity) dan menekuninya secara bersamaan adalah hal yang mustahil.

Berikut ini sebagian karya-karya al-Ghazali dalam berbagai disiplin keilmuan Islam: ${ }^{13}$

\begin{tabular}{|c|c|c|c|c|}
\hline No & $\begin{array}{c}\text { Bidang } \\
\text { Keilmuan }\end{array}$ & No & Judul Buku & Keterangan \\
\hline \multirow[t]{2}{*}{ A } & \multirow[t]{2}{*}{ Tafsir } & 1 & $\begin{array}{c}\text { Jawahir al-Qur'an wa } \\
\text { Duraruh }\end{array}$ & $\begin{array}{l}\text { Karya ini sudah } \\
\text { diterjemahkan ke dalam } \\
\text { bahasa Inggris } \\
\text { (Muhammad Abul } \\
\text { Quaesem, Kuala Lumpur } \\
\text { 1977) dan Itali (Le Perle } \\
\text { Del Corano, Milan, } \\
\text { 2000) }\end{array}$ \\
\hline & & 2 & Qanun al-Ta'wil & $\begin{array}{l}\text { Sanggahan bagi mereka } \\
\text { yang melakukan ta`wil } \\
\text { yang menyimpang dari } \\
\text { aturan al-Qur'an. }\end{array}$ \\
\hline \multirow{4}{*}{$\mathrm{B}$} & \multirow{4}{*}{ Teologi } & 3 & Al-Munqidh min al-Dalal & $\begin{array}{l}\text { Autobiografi pengalaman } \\
\text { spiritual al-Ghazali }\end{array}$ \\
\hline & & 4 & Al-Iqtisad fi al-I'tiqad & $\begin{array}{l}\text { Penjelasan sistem teologi } \\
\text { Ash'ari'ayyah al-Ghazali }\end{array}$ \\
\hline & & 5 & Al-Risalah al-Qudsiyah & $\begin{array}{l}\text { Penjelasan sistem teologi } \\
\text { al-Ghazali yang } \\
\text { kemudian dipadukan } \\
\text { dalam kitab al-Ihya }\end{array}$ \\
\hline & & 6 & $\begin{array}{c}\text { Kitab al-Arba'in fi } \\
\text { Usulal-Din }\end{array}$ & $\begin{array}{l}\text { Pada awalnya merupakan } \\
\text { bagian dari Jawahir al- } \\
\text { Qur'an, kemudian } \\
\text { dicetak secara terpisah. }\end{array}$ \\
\hline $\mathrm{C}$ & Tasawwuf/ & 7 & Ihya 'Ulum al-Din & $\begin{array}{l}\text { Summa al-Ghazali } \\
\text { terhadap ilmu-ilmu }\end{array}$ \\
\hline
\end{tabular}

13 Sumber: al-Ghazali, Al-Mustasfa, 10, Eva Y.N. at. al. (pent.), “al-Ghazali, Abu Hamid”, 113, http://www.ghazali.org/articles/gz1.htm dan http://id.wikipedia.org/wiki/Al-Ghazali\#Catatan. Untuk mengetahui lebih lengkap karya al-Ghazali, baik yang sudah tercetak maupun yang masih makhtutah, bisa dilihat juga dalam al-Ghazali, Asas al-Qiyas, Tahqiq: Fahd b. Muhammad al-Sadhan (Riyadh: Maktabah al-'Abikan, 1993), 16 - 19. Lebih lengkap lagi bisa dilihat kitab yang secara khusus membahas karya-karya al-Ghazali, termasuk sejarah karya-karya tersebut, 'Abd al-Rahman Badwi, Muallafa >t al-Ghazali (Kuwayt: Waka>lah al-Mat\}bu>ah, 1977). 


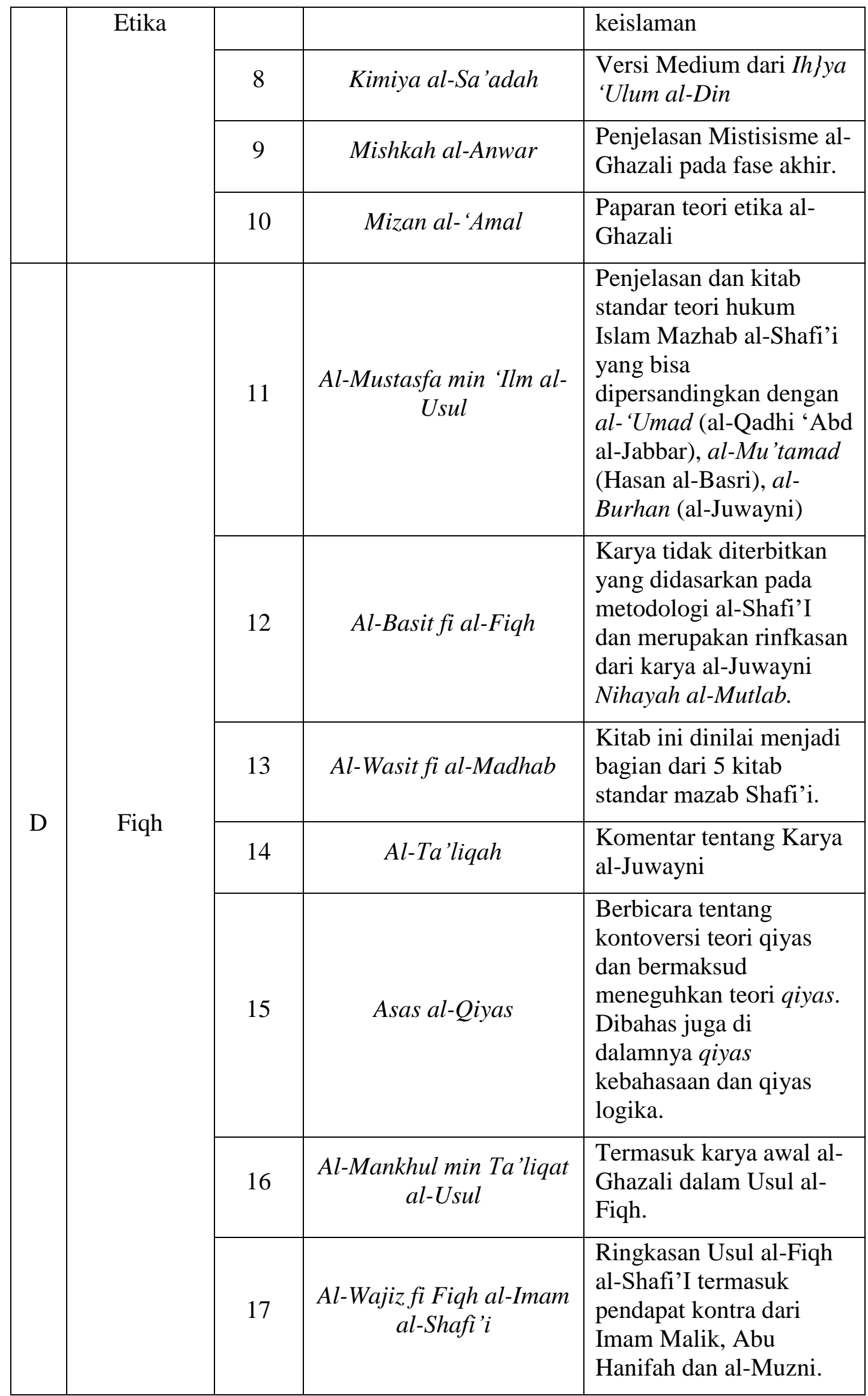




\begin{tabular}{|c|c|c|c|l|}
\hline \multirow{2}{*}{ E } & 18 & Mi'yar al-'Ilm & $\begin{array}{l}\text { Catatan dari logika } \\
\text { Aristoteles }\end{array}$ \\
\cline { 3 - 5 } & \multirow{3}{*}{ Logika } & 19 & Al-Qistas al-Mustaqim & $\begin{array}{l}\text { Usaha untuk melakukan } \\
\text { deduksi kaidah-kaidah } \\
\text { logika dari al-Qur'an dan } \\
\text { menolak sistem logika } \\
\text { 'Isma'ili. }\end{array}$ \\
\hline & 20 & Mihk al-Nazr & Ringkasan Logika Aristo \\
\hline & 21 & Maqasid al-Falasifah & $\begin{array}{l}\text { Ringkasan dari Filsafat } \\
\text { Islam Ibn Sina }\end{array}$ \\
\cline { 3 - 5 } & Filsafat & 22 & Tahafut al-Falasifah & $\begin{array}{l}\text { Kitab ini membahas } \\
\text { kelemahan-kelemahan } \\
\text { filosof kala itu yang } \\
\text { kemudian ditanggapi } \\
\text { oleh Ibn Rushd dengan } \\
\text { Tahafut al-Tahafut }\end{array}$ \\
\hline
\end{tabular}

\section{DESKRIPSI GLOBAL ISI DAN SISTEMATIKA $A L-M U S T A S\} F A$}

Sebelum memasuki bahasan inti, al-Ghazali memulai kitabnya dengan alMuqaddimah. Dalam pendahuluannya al-Ghazali menjelaskan motivasinya menulis al-Mustas\}fa, pemaparan tentang usulal-fiqh dan kajiannya tentang keterkaitan disiplin ini dengan logika Yunani. Motivasinya menulis menurut penuturannya sendiri adalah respon terhadap permintaan para mahasiswanya ketika ia mengajar di Lembaga Pendidikan Nizamiyyah, Naisabur, untuk membuat tulisan tentang usulalfiqh yang sederhana, sistematis akan tetapi bersifat komprehensif. ${ }^{14}$

Selanjut al-Ghazali memaparkan konsepsi keilmuan usulal-fiqh, meliputi definisi usulal-fiqh, posisinya dalam struktur keilmuan Islam dan ruang lingkupnya. Al-Ghazali mendefinisikan usulal-fiqh sebagai ilmu yang mengkaji tentang sumbersumber (origins) hukum, syarat-syarat keabsahannya (validity) dan model, struktur serta metode penunjukannya pada hukum. ${ }^{15}$ Usulal-fiqh sebagaimana terdefinisikan

\footnotetext{
14 Tidak seperti karyanya terdahulu, Tahdhib al-Usul yang dinilai panjang dan kompleks dan tidak juga seperti al-Mankhul yang kelewat ringkas. al-Ghazali, Al-Mustasfa, 14.

15 Ibid., 15. Definisi al-Ghaza>li di atas bercorak filsafati/epistemologis sebagaimana Runes mendefinisikan epistemologi sebagai "Epistemology is the branch philosophy which investigates the origin, structure, methods and validity of knowledge. Lihat, Ahmad Tafsir, Filsafat Umum; Akal dan Hati Sejak Thales Sampai Capra (Bandung: Remaja Rosdakarya, 2001), 23.
} 
tersebut menurutnya adalah ilmu yang mulia karena telah menggabungkan antara potensi nalar dan wahyu. Disiplin ini tandasnya - berbeda dengan ilmu kalam (teologi) yang bersifat kulli - merupakan keilmuan Islam yang bersifat partikular, karena menkonsentrasikan diri pada bahasan dalil-dalil hukum syara'. Ini sebagaimana ilmu tafsir, hadis dan tasawwuf. Dus, secara hirarkis usulal-fiqh berada di bawah payung teologi. Mereka yang belajar usulal-figh diasumsikan telah mapan dalam aspek teologis. ${ }^{16}$ Pandangan dasar (pra asumsi) terkait dengan bahasan usulal-fiqh diterima secara taken for granted dari ilmu kalam. Artinya bahwa usulal-fiqh tidak melakukan verifikasi, karena telah dilakukan oleh ilmu kalam, misalnya tentang hakikat wahyu, kenabian dan syari'at.

Pendefinisian epistemologi usulal-fiqh al-Ghazali (origin, method dan validity) membawa pada implikasi pada ruang lingkup dan sistematika bahasan usulal-Ghazali. Maksud studi usulal-fiqh menurutnya untuk mengetahui "bagaimana menemukan hukum dari dalil". Jawaban atas pertanyaan ini mengimplikasikan pengetahuan detail tentang hukum, dalil dan pembagiannya, bagaimana memeras hukum dari dalil dan kualifikasi subjek yang menemukan hukum. Hukum adalah buah yang tentu mempunyai karakter/ciri, mempunyai (pohon) yang mengeluarkan buah, yang memetik dan cara/metode memetik. Dalam ungkapan lain, usulal-fiqh berkepentingan untuk menjawab; apakah hukum syar' $i$ itu, di mana hukum tersebut ditemukan (apa sumber hukum itu), bagaimana cara/metode menemukan hukum dan siapa yang berwenang menggali hukum tersebut? Karena itu, ruang lingkup dan sistematika kajian usulal-fiqh al-Ghazali meliputi 4 poros bahasan, sebagaimana tergambar di bawah ini berikut break down masing-masing poros:

16 al-Ghazali, Al-Mustasfa, 17. 


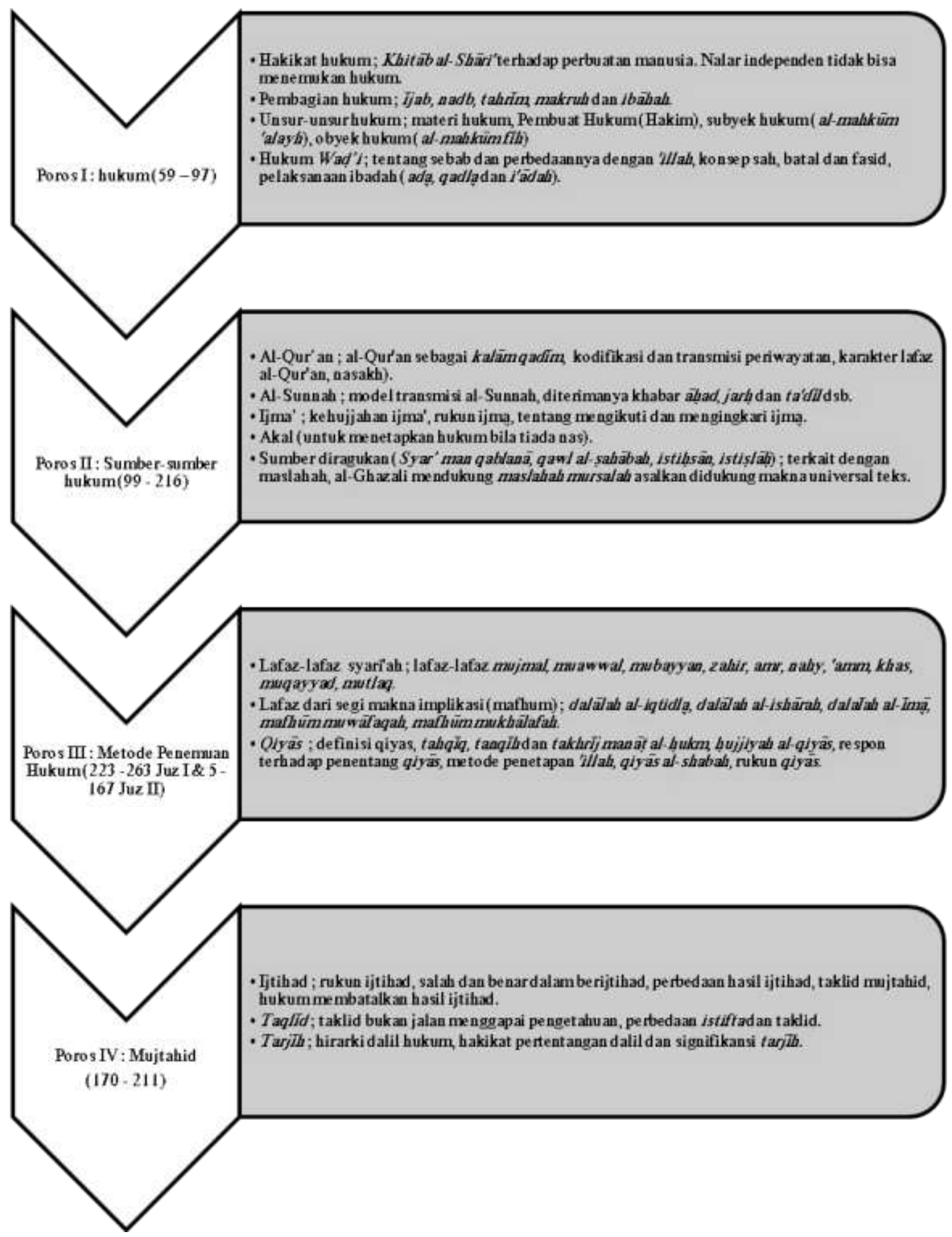

Berdasar karakteristik bahasan di atas, maka al-Mustasfa al-Ghazali termasuk kitab yang mengambil garis manhaj al-mutakallimin. Manhaj ini berupaya untuk melakukan kajian persoalan usuliyyah secara tuntas dengan kajian yang bersifat teoritis dan menghindari persoalan-persoalan khilafiyyah dan furu'iyyah. Hal ini 
karena tujuan metode ini adalah memperoleh kaidah usuliyyah yang kuat. Ciri lain dari metode ini adalah usaha merelevansikan kaidah usuliyyah dengan dilalah al-laf dan prinsip-prinsip kebahasaan. ${ }^{17}$

\section{AL-GHAZALI, LOGIC DAN QIYAS USULAL-FIQH}

Kebanyakan tela`ah terhadap al-Mustasfa min 'Ilm al-Usulmenkonsentrasikan diri pada bahasan hukum murni, tidak pada keterkaitan hukum dengan kaidah logika sebagaimana yang ditawarkan al-Ghazali. Al-Mustasfa adalah kitab usulpertama yang menjadikan uraian-uraian prinsip logika sebagai pengantarnya. Ini mengisyaratkan bahwa al-Ghazali hendak mensintesakan atau menjadikan logika sebagai basis penalaran hukum sebagaimana telah dikatakannya sendiri bahwa mereka yang menyepelekan logika/mantik, maka keilmuannya tidak dianggap thiqah. Pengantar logikanya tidak berarti hendak menjadikan logika sebagai bagian dari usulal-fiqh, akan tetapi logika menjadi pengantar dan dasar semua keilmuan, termasuk usulal-fiqh (wa laysat hadzih al-muqaddimat min jumlah 'ilm al-usulwa la min muqaddimatih al-khassah bih, bal hiya muqaddimah al-'ulum kulluh, wa man la yuhit biha fala thiqata lahu bi'ulumih aslan). ${ }^{18}$

Logika secara singkat didefinisikan sebagai disiplin yang mengkaji metodemetode dan prinsip-prinsip yang dipakai untuk membedakan yang benar dari yang salah dari proses penalaran. ${ }^{19}$ Dalam kajian logika, tidak saja mensyaratkan "kesimpulan" yang diambil dari premis-premis harus benar, akan tetapi bentuk teoritik atau form berpikir juga harus benar dan logis. Karena itu untuk memperoleh pengetahuan yang benar mensyaratkan bentuk berpikirnya juga harus benar.

\footnotetext{
17 Selain al-Mustasfa, kitab yang menganut metode al-mutakallimun (metode Shafi'iyyah) antara lain adalah karya al-Shafi'I sendiri, al-Risalah, Abu al-Husayn al-Bas\}ri, al-Mu'tamad fi Usul al-Fiqh, alJuwayni, al-Burhan fi Usul al-Figh, al-Shayrazi, al-Luma', dan lainnya. Sementara metode yang lain dalam penulisan usul al-fiqh adalah manhaj al-Ah\}naf yang secara umum mempunyai karakter yang berseberangan dengan metode al-Mutakallimun dan metode yang mencoba menggabungkan dua metode di atas. Lihat Khalid Ramadan Hasan, Mu'jam Usul al-Figh (Mesir: al-Rawdah,1998), 8.

18 Ibid., 12.

${ }^{19}$ Irving M. Copy, Introduction to Logic (New York: Macmillan Publishing Co., Inc., 1978), 3.
} 
Sebagai sebuah pengantar, uraian prinsip-prinsip logik tidak sedetail uraian al-Ghazali dalam kitab-kitabnya yang lain yang khusus mengkaji logika Yunani, Mi'yar al- 'Ilm ${ }^{20}$ dan Mihk al-Nazr. Secara umum pengantar logikanya (al-Mustasfa, hlm. 12 - 58) membahas tentang al-had (definisi) dan al-burhan. Dalam memperoleh pengetahuan, manusia harus melewati dua proses keilmuan, pertama adalah penemuan makna zat-zat yang bersifat mufrad (idrak al-dzawat almufradah), sebagaimana pengetahuan kita tentang makna jism (tubuh), hjarakah (gerakan), alam, hadis (baru) dan qadim (lama) serta makna-makna mufrad yang lain. Kedua adalah penisbahan atau membangun relasi antar makna-makna individual tersebut baik dengan model negasi (nafy) atau afirmasi (ithbat) sehingga bangunan relasi tersebut bisa dinilai benar atau salah. Sebagai misal penisbahan "alam" dan "baru" yang bersifat afirmatif; "alam adalah baru" (al- 'alam hadis), atau menisbahkan "qadim" (tidak berpermulaan) terhadap "alam" dengan model negasi; "alam tidak bersifat qadim" (lays al-'alam qadiman). ${ }^{21 .}$ Karena itu di kalangan Ahli Mantik dikenal tasawwur - tasdiq dan ma'rifah - 'ilm. Tasawwur adalah pengetahuan dan persepsi terhadap entitas-entitas yang bersifat individual atau pengetahuan tentang konsep dan menghasilkan ma'rifah, sementara tasdiq adalah pengetahuan tingkat lanjut berdasar relasi antar entitas atau proposisi dan menghasilkan ilm. Yang pertama adalah wilayah kajian al-had (definisi) dan alrasm, yang kedua wilayah al-burhan (qiyas, istiqra` dan metode penalaran lain). alHad dan al-burhan adalah alat untuk memperoleh pengetahuan yang bersifat kasbi (al-'ulum al-matlubah).

Selanjutnya al-Ghazali menguraikan tentang al-h\}ad, prinsip-prinsip dan verifikasi terhadap prinsip-prinsip tersebut. Makalah ini tidak akan mengungkap persoalan al-had, akan tetapi lebih menkonsentrasikan diri pada wilayah konstruksi makna atau al-burhan. ${ }^{22}$ Al-burhan adalah bentuk aktivitas nalar deduktif yang

\footnotetext{
${ }^{20}$ Lihat, Al-Ghazali, Mi'yar al-'Ilm, Ed. Shams al-Din (Beirut: Dar al-Kutub al-`Ilmiyyah).

21 al-Ghazali, Al-Mustas\}fa, 12.

22 Tentu karena keterbatasan tulisan ini, persoalan al-had tidak dikupas. Walaupun pada dasarnya, menurut al-Ghazali, berbicara tentang al-burhan adalah berbicara tentang muqaddimah dan berbicara tentang muqaddimah (premis) tentu berbicara tentang subjek-predikat premis (mahkum 'alayh$h u k m / m a w d u^{\prime}-m a h m u l$ ) dan ini berarti berbicara tentang al-had (persoalan konsep, lafaz dan petunjuknya). Lihat, Lihat, Al-Ghazali, Mi'yar al-'Ilm, 41 - 42.
} 
berangkat dari dua premis (muqaddimah) yang diketahui sebelumnya, disusun secara khusus, dengan syarat-syarat khusus, yang kemudian premis tersebut melahirkan kesimpulan (natijah). ${ }^{23}$ Al-burhan dengan definisi sebagaimana tersebut penting untuk diungkap sebagai pembanding teori qiyas dalam usulal-fiqh. Contoh dari al-burhan, misalnya;

setiap tubuh(jism) pasti tersusun,

dan setiap yang tersusun adalah pasti baru,

maka setiap tubuh (jism) pasti adalah baru.

Contoh yang lain yang secara materi sering diungkap dalam usul al-fiqh adalah;

setiap nabidz (perahan anggur) adalah memabukkan,

dan setiap yang memabukkan hukumnya haram,

maka tiap nabidz harus dihukumi haram.

Inilah contoh relasi dua muqaddimah yang menghasilkan natijah. Menurut al-Ghazali, jika premis-premis diakui sebagai benar, maka natijah dengan sendirinya harus diterima.

Al-Ghazali menambahkan bahwa jikalau premis-premis yang ada bersifat definitif (qat'iyyah), maka penalaran dengan premis ini disebut dengan al-burha>n (deduksi-silogisme). Di bawah al-burhan adalah qiyas jadali dengan premis yang diterima/diakui. Dan jika premis-premisnya bersifat zanni, maka disebut dengan qiyas fiqhi (legal analogy). Jika disebut asl qiyas, maka setiap premis (muqaddimah) pada dasarnya adalah asl. Bangunan dua asl menghasilkan natijah. Para yuris umumnya bernalar: nabidz (perahan anggur) memabukkan, maka ia dihukumi haram, diserupakan (qiyas) dengan khamr. Pengetahuan tentang efek mabuk dari nabidz adalah dengan observasi dan pengalaman, sementara keharaman minuman memabukkan didasarkan pada khabar; "kullu muskir haram”. ${ }^{24}$

\footnotetext{
23 al-Ghazali, Al-Mustasfa, 44.

24 Ibid.
} 
Dari paparan di atas dapat diketahui bahwa penalaran al-burhan mensyaratkan adanya dua muqaddimah/premis mayor dan minor;

a. Premis I : Tiap nabidz memabukkan. Terdiri dari subjek dan predikat (mubtada' dan khabar). Subjek sebagai mahkum 'alayh dan predikat sebagai hukm.

b. Premis II : Setiap yang memabukkan adalah haram. Unsur-unsurnya sebagaimana premis I.

c. Natijah/Konklusi : Maka, tiap nabidz dihukumi haram.

Karena itu maka, dalam al-burhan terdapat 4 unsur, hanya saja satu unsure diantara empat tersebut diulang penyebutannya dalam premis berikutnya, dan inilah yang menyatukan dua premis tersebut. Unsur ini dalam qiyas fiqhi disebut dengan 'illah yang dalam contoh di atas adalah “memabukkan”. 'Illah tersebut dalam teori silogisme disebut dengan term tengah (al-had al-awsat/middle term). Term tengah ini adalah term ketiga dari silogisme yang tidak disebut dalam konklusi, akan tetapi muncul dalam kedua premisnya yang berfungsi menyatukan keduanya. Sedangkan dua term yang lain adalah term mayor dan term minor. Term minor berfungsi sebagai subyek konklusi (tiap nabidz) sedang term mayor berkedudukan sebagai predikat konklusi (dihukumi haram).

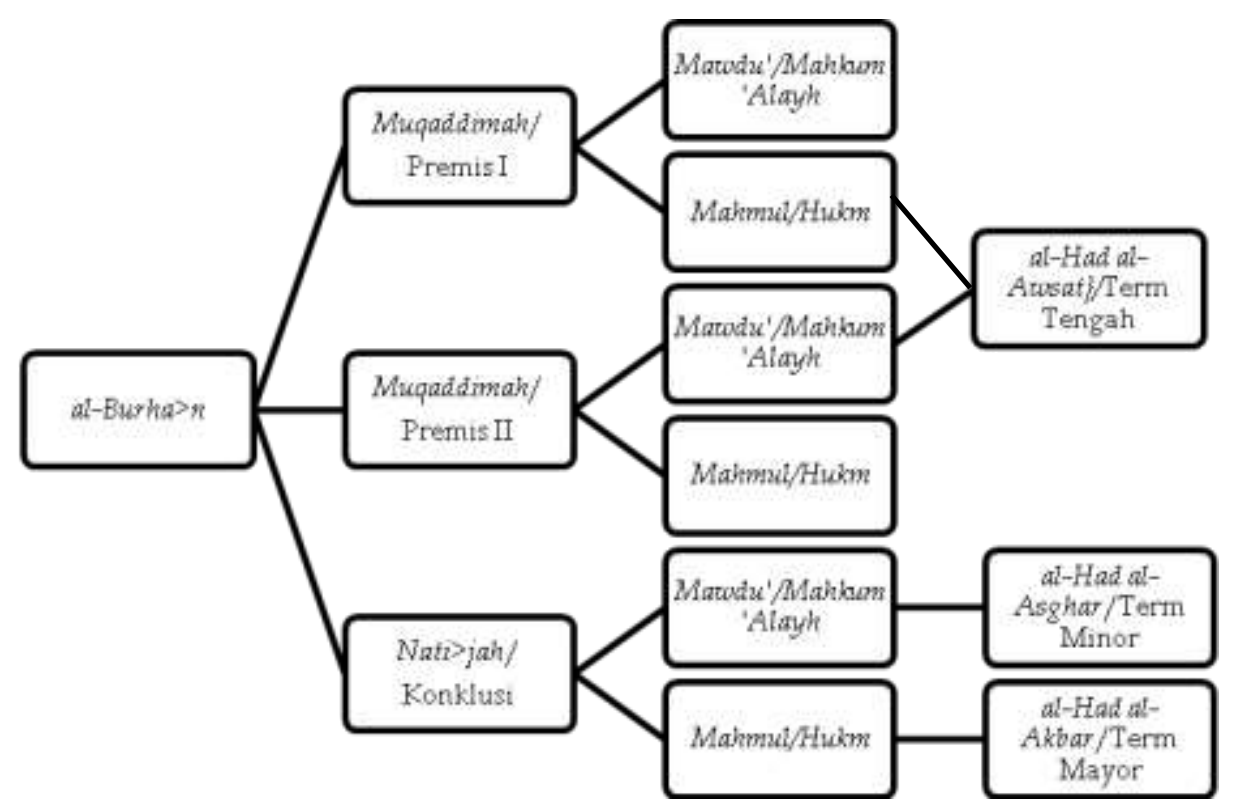


Itulah kerangka penalaran al-burhan menurut al-Ghazali atau silogismedemonstratif dalam bahasa Yunani. Sementara itu qiyas fiqhi sebagaimana definisi yang dipilih al-Ghazali adalah : "haml ma'lum 'ala ma'lum fi ithbati hukm lahuma aw nafyihi 'anhuma bi amr jami' baynahuma min ithbat hukm aw sifah aw nafyihi 'anhuma". ${ }^{25}$ Pilihan kata "haml" menunjukkan bahwa qiyas merupakan usaha dan kreasi mujtahid, sementara itu karena asl dan far' dalam qiyas tidak selalu bersifat afirmatif, maka penggunaan kata “ma'lum”, bukan shay` (sesuatu) lebih tepat. Sesuatu yang bersifat negasi/ma’dum bukanlah shay` (sesuatu).

Lebih jauh al-Ghazali mengatakan bahwa definisi qiyas cukup beragam, sebagian lebih luas dari cakupan qiyas itu sendiri dan vice versa. Sementara itu definisi qiyas yang dilontarkan para filosof, tarkib muqaddimatayn yahsul min huma natijah, juga terlalu jauh dari hakikat qiyas fiqhi itu sendiri. Dalam kitabnya Mi'ya $>$ r al-'Ilm, al-Ghazali mengatakan bahwa hujjah atau pola nalar keilmuan yang bersifat tasdiqiyyah ada tiga; qiyas, istiqra dan tamthil. Tamthil yang dimaksudkannya adalah al-qiyas al-figh, atau rad al-ghaib 'ala al-shahid menurut mutakallimun dan tashbih menurut ahli bahasa. Sementara qiyas yang dimaksudkan dalam buku tersebut adalah al-burhan atau silogisme demonstrative. ${ }^{26}$ Qiyas juga tidak sama dengan ijtihad, qiyas dan ijtihad bukan ismani li ma'n wahid ${ }^{27}$ sebagaimana dilontarkan al-Shafi'i. Ijtihad lebih luas cakupannya dari qiyas, ia bisa meliputi varian metode selain qiyas. al-Ghazali membedakan konsep-konsep berikut; tafakkur, tadabbur, istinbat, qiyas dan ijtihad.

\footnotetext{
25 Ibid., 96. Lihat juga al-Ghazali, Asas al-Qiyas, 13 - 14.

${ }^{26}$ Al-Ghazali, Mi'yar al-'Ilm, 111.

27 Muh \}ammad b. Idris al-Shafi'i, al-Risalah, ed. Ahmad Muhammad Shakir (Beirut: Dar al-Kutub al'Ilmiyah, t.t.) , 477. Berdasar ungkapan al-Shafi'i di atas, Sulaiman Abdullah menilai bahwa ijtihad menurut al-Safi'i hanyalah qiyas, bukan teori-teori yang lain. Dengan kata lain, ijtihad identik atau sinonim dengan qiyas. Ia tidak menerima teori ijtihad yang lain. Lihat Sulaiman Abdullah, Dinamika Qiyas dalam Pembaharuan Hukum Islam; Kajian Konsep Qiyas Imam Syafi'i (Jakarta: Pedoman Ilmu Jaya, 1996),108. Ijtihad sebenarnya adalah terma umum berupa penggunaan nalar manusia untuk mengelaborasi hukum, terma tersebut mengkaver varian proses mental sejak dari interpretasi teks sampai penilaian terhadap otentisitas tradisi. Karena itu, qiyas hanyalah bagian dari makna ijtihad. Lihat Coulson, N. J. Coulson, A History of Islamic Law (Edinburgh: Edinburgh University Press), 59.
} 
Dari contoh-contoh sebelumnya, bentuk-bentuk al-burhan memang identik dengan qiyas fiqhi dan kemestian konklusi/natijah memang tidak bisa dipungkiri sebagai hasil dari bangunan relasi premis. Akan tetapi menurut al-Ghazali, qiyas fiqhi menuntut relasi antar premis adalah relasi kesamaan dan kedekatan (almusawah wa al-muqarabah). Hal ini antara lain dapat dibuktikan dari penggunaan makna etimologis qiyas dalam ranah budaya Arab. qiyas secara etimologis adalah:

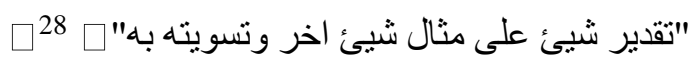

Artinya, qiyas adalah mengukur sesuatu dengan sesuatu yang lain dan "قاس الثئ بغيره او على menyamakannya). Dalam al-Munjid fi al-Lughah disebutkan غيره", yang artinya, "قدره على مثاله",29 atau mengukur, membandingkan sesuatu dengan yang semisalnya. Hallaq menegaskan bahwa hukum Islam pada dasarnya adalah case law. sifat fiqh yang kasuistik, concern pada kasus-kasus individual dari pada aturan yang bersifat general, maka penalaran fiqh dengan pola kasus ke kasus dan bagian ke bagian lain, atau yang disebut dengan legal analogy menjadi sangat relevan. ${ }^{30}$

Selain itu al-Ghazali juga menyatakan bahwa pada dasarnya qiyas fiqhi adalah qiyas shabah, atau karakter dan penamaan shabah bisa dilekatkan pada qiyas. Karena penisbahan far' pada asl lebih didasarkan pada jami'/'illah yang diserupakan antara asl dan far'.31 Karena itu, sebagian berpendapat bahwa qiyas fiqhi mempunyai fungsi etimologis yang sama dengan tashbih. 'illah (al-jami') sendiri dalam disiplin usulal-fiqh dipersyaratkan untuk munasib (berkesesuain). Almunasib dari segi bahasa adalah al-muqarabah, karenanya munasib-nya 'illah bisa bermakna sifat yang mendekatkan (approach) pada hukum (al-wasf al-muqarib li al-hukm). ${ }^{32}$

\footnotetext{
${ }^{28}$ Muhammad 'Abid al-Jabiri, Bunyah al-'Aql al-'Arabi (Beirut: al-Markaz al-Thaqafi al-'Arabi, 1993), 137.

${ }^{29}$ Louis Ma'luf, al-Munjid fi al-Lughah (Beirut: Dar al-Mashriq, 1998), 665.

30 Wael B. Hallaq, Law and Legal Theory in Classical and Medieval Islam (Burlington: Ashgate, 1995), 85. 31 al-Ghazali, Al-Mustasfa,141. Qiyas shabah atau juga t\}ard berbeda dengan qiyas yang 'illah-nya bersifat mu'aththir atau mula im.

32 Al-Jabiri, Bunyah, 244.
} 
Hal tersebut di atas tidak lepas dari penegasan al-Ghazali di pengantar logikanya dalam al-Mustasfa bahwa qiyas fiqhi berbeda dengan qiyas jadali dan qiyas burhani. Premis-premis qiyas fiqhi bersifat spekulatif (zan). Hal itu disebabkan 'illah hukum asl tidak secara eksplisit disebutkan, akan tetapi digali sendiri oleh yuris dan diselidiki keberadaannya pada far'. Qiyas model ini disebut dengan “al-qiyas al-khafi”. Model qiyas inilah yang disebut al-Ghazali sebagai ijtihad di dalam mengeluarkan dan meng-intinbat-kan isyarah hukum (takhrij manat al-hukm wa istinbatuh). ${ }^{33}$ Menurut al-Ghazali, 'illah yang bersifat mustanbatah pada dasarnya tidak boleh dijadikan dasar penetapan hukum, akan tetapi ada isyarat-isyarat dan eksplanasi teks yang membolehkannya, termasuk pengalaman sejarah menunjukkan wajibnya ta'lil (rasionalisasi hukum). karenanya ia tidak berbeda dengan tahqiq dan tanqih manat al-hukm. ${ }^{34}$

Senada dengan hal di atas, Ibn Taymiyyah - walaupun menolak pendapat yang menyatakan bahwa qiyas usul al-fiqh bersifat inferior terhadap qiyas burhan (silogisme) mengakui bahwa titik lemah qiyas fiqhi terletak pada subtansi material premis, khususnya pada 'illah. Ia mengatakan, sebagaimana dikutip oleh Hallaq, : “Jika subtansi material premis bersifat pasti, tanpa memandang bentuk penalaran analogi atau silogisme, maka konklusi yang diperoleh juga bersifat pasti”. Ibn Taymiyyah menandaskan, sebagaimana juga terlihat dalam uraian di atas, bahwa dari sisi bentuk (form), analogi (qiyas) equivalent dengan silogisme (al-burhan). ${ }^{35}$

Karena itu maka premis qiyas fiqhi secara materi seyogyanya ditingkatkan derajad kepastiannya dengan lebih menyandarkan premis-premisnya pada kulliyatkulliyat shar'iyyah dan maqasid shar'iyyah dan bukan pada 'illah yang sering kali terjebak pada persoalan kebahasaan dan teologi. Penalaran qiyas fiqhi pada dasarnya berada dalam bingkai ma'qul al-nas, yakni transfer hokum asl ke far' bersandar pada kandungan teks (ma'qul al-nas), akan tetapi kandungan teks tersebut diperoleh dengan orientasi berlebihan pada dila $>l a h$ al-khit $\} a>b$ (petunjuk

\footnotetext{
33 Ijtihad model di atas banyak diperselisihkan oleh penentang teori qiyas. Itu berbeda dengan ijtihad model tahqiq manat al-hukm dan tanqih manat al-hukm. Lihat, al-Ghazali, Al-Mustasfa, 97 - 99.

34 Ibid., 99.

${ }^{35}$ Hallaq, Law and Legal Theory, 94.
} 
wacana) yang focus tela`ahnya pada hubungan lafaz dan makna yang bersifat problematic (ishkaliyyat al-lafz wa al-ma'na). selain itu dari sisi teologis, menjadikan 'illah sebagai motif dan kausa hokum mengundang kontoversi berkaitan dengan apakah kehendak Tuhan dibatasi dengan tujuan dan kausa tertentu atau bersifat mutlak. Karena itulah, al-Jabiri menilai bahwa bahwa teori qiyas dalam usul al-fiqh terjebak pada tiga otoritas (sult\}ah); sult\}ah al-lafz, sult\}ah al-as $\} l$ dan sult\}ah al-tajwiz.

Hallaq dalam kajiannya perbandingannya antara system hokum Islam dan system Common Law menyimpulkan bahwa hokum Islam lebih banyak memprioritaskan konsistensi logic dan mengabaikan pertimbangan-pertimbangan lain, termasuk perubahan hokum. Dan ini dinilai sebagai negative vis a vis prinsip dinamika dan elastisitas hukum Islam. ${ }^{36}$ Karena itu, penalaran hukum yang bersifat analitik - dengan memperhatikan logika deduktif yang berasal dari premis-premis yang bersifat aksiomatik - perlu juga diimbangi dengan penalaran hukum yang bersifat non-analitik, yakni dengan melibatkan sudut pandang yang komprehensif, termasuk sisi-sisi kemanusiaan manusia dan moralitas.

\section{F. PENUTUP}

Dari studi terhadap magnum opus hukum Islam al-Ghazali, al-Mustas $\} f a$ min 'Ilm al-Usulada beberapa benang merah yang bisa diambil:

1. Al-Mustasfa al-Ghazali adalah satu-satunya kitab yang menjadikan bahasan logika sebagai pengantarnya. Itu artinya al-Ghazali mencoba melakukan integralisasi usul al-fiqh dengan disiplin lain untuk pengembangan disiplin ini.

2. Kajiannya pada logika membawa pada kesimpulan bahwa qiyas fiqhi berbeda dengan al-burhan/silogisme, karena premis qiyas fiqhi bersifat spekulatif.

${ }^{36}$ Ibid. 
3. Penting untuk mendekatkan qiyas fiqhi dengan qiyas burhani agar fiqh sebagai sebuah keilmuan mempunyai validitas yang yang diakui. Akan tetapi wacana penalaran fiqh yang bersifat non-analitik-pun perlu dikembangkan untuk menjaga keseimbangan antara aspek tekhnikalisme hukum dan aspek kemanusiaan dan moralitas.

4. Subtansi al-Mustasfa pada dasarnya merupakan usaha untuk merekonsiliasikan dan mensintesakan peran akal dan wahyu dengan porsi dan wilayah masing-masing.

5. Al-Mustas $\} f a$ adalah kitab usul yang ditulis dengan menggunakan metode ahli ilmu kalam (Shafi'iyyah). Ciri metode penulisan ini sebagaimana ada dalam al-Mustasfa adalah:

a. Memusatkan pada kajian yang bersifat teoritis untuk menghasilkan kaidah usul yang kuat, walau terkadang berseberangan dengan mazab penulisnya.

b. Kajian kebahasaan yang kuat.

c. Menghindari hal-hal yang bersifat furu dan fanatisme mazab.

6. Dilihat dari muatan ideologis, al-Mustasfa pada dasarnya adalah sosialisasi dan penguatan mazab hukum ahl al-sunnah/Shafi'iyyah. Itu tidak terlepas keterkaitan erat al-Ghazali dengan Perguruan Nizamiyyah yang didirikan untuk membendung pengaruh syi'ah dan menyiapkan pengisian jabatan-jabatan publik yang beraliran ahl al-sunnah. 


\section{DAFTAR PUSTAKA}

Abdullah, Sulaiman. Dinamika Qiyas dalam Pembaharuan Hukum Islam; Kajian Konsep Qiyas Imam Syafi'i. Jakarta: Pedoman Ilmu Jaya, 1996.

Al-Ghazali, Abu Hamid Muhammad b. Muhammad b. Muhammad. Al-Mustasfa min 'Ilm al-Usul. Beirut: Dar Ihya' al-Turath al-'Arabi, 1997.

Asas al-Qiyas, Tahqiq: Fahd b. Muhammad al-Sadhan (Riyadh: Maktabah al-'Abikan, 1993.

'Ilmiyyah).

Mi'yar al-'Ilm, Ed. Shams al-Din (Beirut: Dar al-Kutub al-

Al-Jabiri, Muhammad 'Abid. Bunyah al-'Aql al-'Arabi. Beirut: al-Markaz alThaqafi al-'Arabi, 1993.

al-Shafi'i, Muhammad b. Idris. al-Risalah. ed. Ahmad Muhammad Shakir. Beirut: Dar al-Kutub al-'Ilmiyah, t.t.

Anwar, Syamsul. Epistemologi Hukum Islam dalam al-Mustasfa min 'Ilm al-Usul Karya Imam al-Ghazali $(450$ - 505 H/1058 - 1111 M). Yogyakarta: IAIN Sunan Kalijaga, 2000.

Badwi, 'Abd al-Rahman. Muallafat al-Ghazali. Kuwayt: Wakalah al-Matbuah, 1977.

Copy, Irving M. Introduction to Logic. New York: Macmillan Publishing Co., Inc., 1978.

Coulson, N. J. A History of Islamic Law. Edinburgh: Edinburgh University Press.

Dahlan, Abdul Aziz et. al. (ed.). Ensiklopedi Hukum Islam. Jakarta: P.T. Ichtiar Baru van Hoeve, 2003.

Eva Y.N. at. al. (pent.), “al-Ghazali, Abu Hamid”, Ensiklopedi Oxford. Jakarta: Mizan, 2002.

Hallaq, Wael B. Law and Legal Theory in Classical and Medieval Islam. Burlington: Ashgate, 1995.

Hasan, Khalid Ramadan. Mu'jam Usul al-Fiqh. Mesir: al-Rawdah,1998.

Isma'il, Sa'ban Muhammad. Usulal-Fiqh; Tarikhuh wa Rijaluh. Mekkah: Dar alSalam, 1998.

Ma'luf, Louis. al-Munjid fi al-Lughah. Beirut: Dar al-Mashriq, 1998. 
Jurnal Keislaman, Vol. 1, No. 1, Maret

Tafsir, Ahmad. Filsafat Umum; Akal dan Hati Sejak Thales Sampai Capra. Bandung: Remaja Rosdakarya, 2001. 